\title{
ON THE RELATIVE ECONOMY AND DURABILITY OF VARIOUS CLASSES OF STATIONARY STEAM BOILERS.
}

By Mr. Roberi B. LONGRIDGE, of Manchester.

The object of the present paper is to lay before the members of the Institution some statistics relating to Stationary Steam Boilers, showing the relative economy of the various classes of boilers usually employed for manufacturing purposes, and accompanying these statistics by remarks upon the advantages and imperfections peculiar to each class. The data here recorded and the opinions deduced are the result of many years' experience, during which the writer's position has afforded him unusual facilities for investigating this important subject : the boilers referred to in the following remarks exceed $\mathbf{1 6 0 0}$ in number taken indiscriminately.

The following Table I, with the boilers divided into classes, shows the numerical ratio which these bear to each other, and may be considered a fair average of what are at present in use in the great manufacturing districts of Lancashire and Yorkshire :-

\section{TABLE I.}

Proportionate Number of different Boilers now working.

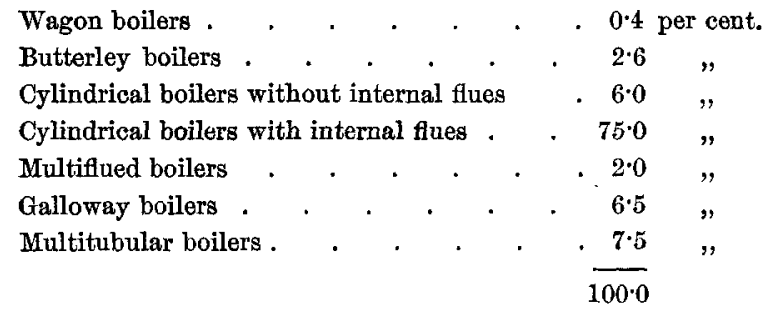

This table shows that the class of boilers which have internal flues, commonly known as Cornish boilers, greatly preponderates, being no less than 75 per cent. of the whole. This proportion has reference to all boilers now working, and large as it may appear would be still 
further augmented if reference were made only to those manufactured during the last two or three years, in which case the proportion of boilers with internal flues could not be estimated at less than 90 per cent. of the whole number of boilers made during that period. In consequence of this very large excess of one particular class of boiler, it will be well to enquire whether it arises from any decided superiority of boilers with internal flues, or merely from the habit of imitation which so generally prevails. Although these boilers do undoubtedly possess advantages over those which they have in a great measure superseded, it will be seen from the particulars given hereafter that they are inferior to other boilers of more recent introduction.

It has been found impossible to determine satisfactorily from the data which have been collected the correct relative economy of the several classes of boilers here referred to, inasmuch as the only common standard of comparison is the indicated horse power of the engines, which is evidently fallacious; for any difference in the degree of expansion of the steam used must affect the results, and in some cases to a great degree. Calculations based on such uncertain data must therefore be received with much caution; but as it may be of some interest to know the average consumption of fuel per indicated horse power in the manufacturing districts, this is given in Table II (appended), in which each class of boiler is distinguished, but no attempt is made to deduce any conclusions as to their comparative economy further than may be confirmed by individual experiments. Wherever boilers differing in construction have been working together it has been necessary to exclude these from the table; and as this is the case in a large proportion of factories, the number of boilers here referred to is comparatively small. Where the engines have not been indicated or the requisite particulars not obtained, the boilers have also been omitted. The following are the general results of Table II :-

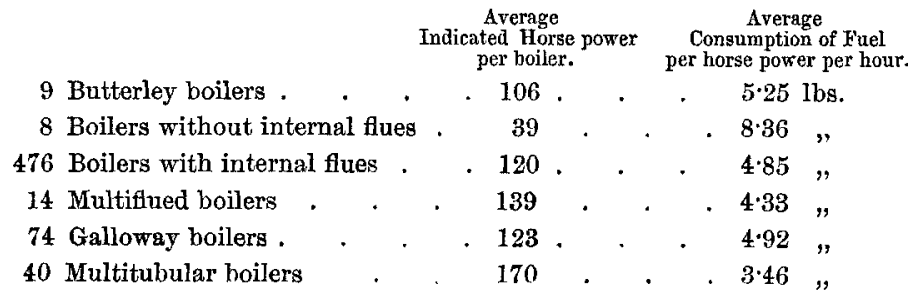


Table III (appended) shows the evaporative duty of the various classes of boilers, as ascertained from experiments made with boilers working under their usual conditions. The general construction of the boilers experimented upon is shown in Plates 31 and 32, and they are distinguished in the Tables by the following letters of reference :A-Cylindrical boiler with 2 flues.
B- Ditto
ditto.
C- Ditto
ditto
shown in Figs. 1 and 2, Plate 31.
D- Ditto with 5 flues shown in Figs. 3 and 4, Plate 31 .
E-Multiflued boiler with 7 flues shown in Figs. 5 and 6 , Plate 31 . F-Galloway boiler.
G- Ditto shown in Figs. 7, 8, and 9, Plate 32 .
E-Galloway Multitubular boiler shown in Figs, 10 to 13, Plate 32.
I -Multitubular boiler shown in Figs. 14 to 17, Plate 32.

In these experiments the fuel consumed was weighed, and the water evaporated was accurately measured by Kennedy's water meters, on the correctness of which great dependence may be placed from the high character they have deservedly acquired. The evaporative duty of the different boilers is given in Table III in lbs. of water evaporated from $62^{\circ}$ Fahr. per lb. of fuel consumed; and a column is also added showing the equivalent quantity of water evaporated from $212^{\circ}$ Fahr., for convenience of comparison with results calculated from the latter temperature. The following are the general results of Table III :-

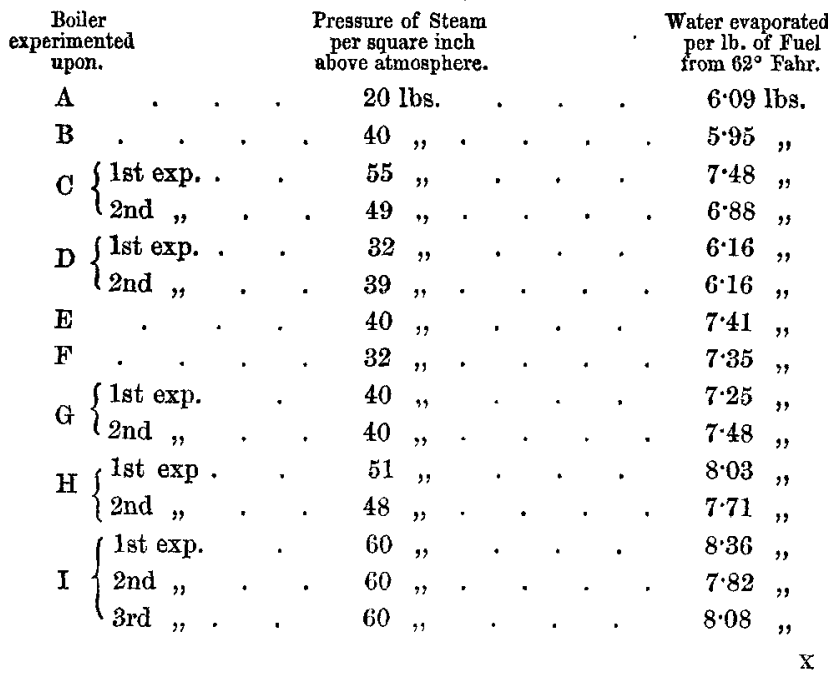


The area of heating surface in the different boilers experimented upon is given in Table IV (appended) together with the area of firegrate; that only being reckoned as heating surface which can fairly be considered effective in generating steam. The following are the total areas in each case :-

\begin{tabular}{|c|c|c|c|c|c|c|c|c|c|c|c|}
\hline Boiler. & & & & Area of Fir & egrate & & & & Area of & Heating & Surface. \\
\hline$A$ & . & . & . & $\quad 38 \mathrm{~s}$ & q. ft. & & . & - & . & $590 \mathrm{sc}$ & $\mathrm{gq} . \mathrm{ft}$ \\
\hline B & . & . & . & 35 & $"$ & & . & & . & 540 & $"$ \\
\hline C & . & . & . & 30 & $"$ & . & . & . & . & 463 & $"$ \\
\hline $\mathrm{D}$ & . & . & . & 30 & " & & . & . & . & 530 & , \\
\hline $\mathbf{E}$ & . & . & . & 52 & $"$ & . & . & . & . & 697 & $"$ \\
\hline F & . & . & . & 30 & $"$ & & . & . & . & 499 & " \\
\hline$G$ & . & . & . & $38 \frac{1}{2}$ & , & . & . & . & . & 898 & , \\
\hline $\mathbf{H}$ & . & . & . & 30 & , & & . & . & . & 599 & " \\
\hline I & . & . & . & 30 & $"$ & . & . & . & . & 454 & " \\
\hline
\end{tabular}

In Table IV the several kinds or positions of heating surface are distinguished, not only as furnace and flue surfaces, but also as convex, concave, and vertical surfaces: for the value of any surface must depend much upon its position relative to the source of heat, the direction of the gases from the furnace, and the degree of circulation of the water in the boiler; or, in other words, upon the more or less favourable position of the surface for receiving or taking up the heat, and on the facility with which the heat is communicated by means of the circulation of the water. In the internal flues or tubes of boilers the deposit of dust and ashes from the fuel greatly retards the transmission of heat through the plates: on this account, and from the unfavourable position of the lower half of cylindrical flues and also of horizontal surfaces forming the underside of flues or combustion chambers, it has been usual to exclude these in estimating the area of heating surface, as is the case in the areas given in Table IV. From the frequent fracture of plates in these parts however, in consequence of overheating, it is evident that these surfaces do absorb and accumulate heat in sufficient amount to cause damage to the metal; by proper circulation of the water this might be prevented and steam generated, though possibly not to any practically useful extent. Upper horizontal surfaces, such as the crowns of square fireboxes and combustion chambers, have hitherto been generally considered the most 
effective. This seems however to be exceedingly questionable, particularly with regard to horizontal surfaces of large extent : for a surface can only be relatively effective in proportion to the rapidity with which the communicated heat can be carried off by the water; and the maximum of efficiency will be attained when no accumulation of heat takes place in the plates, which must depend entirely on the circulation of the water. There can be no question that horizontal surfaces are the best to absorb heat; but unless the heat be carried off by the water and prevented from accumulating in the plates, the practical value of the surface for generating steam will be much impaired and the plates speedily injured: hence those surfaces are to be preferred, which combined with naturally good positions for absorbing heat offer also the greatest facility for circulation of the water. Since in the case of horizontal surfaces, particularly of large extent, the currents of water tending towards the middle from the outside or from above, can reach the middle only by opposing the ascending currents of steam and water, they must of necessity be more or less diverted from their course; and the circulation being thus interrupted, not only will the generation of steam be less than the surfaces are capable of producing, but as a necessary and more serious consequence the plates must be subjected to constant overheating, and sooner or later will become deformed and seriously injured. Under these circumstances an accumulation of deposit usually takes place, which has been assigned as the cause of the injuries and fractures of the plates, where these have occurred; though in reality the presence of deposit affords evidence only of comparative quiescence or imperfect circulation of the water at these parts, of which it is the effect. On this account therefore upper horizontal surfaces, especially when of large extent, cannot be the most effective, nor even so effective as has generally been supposed; indeed when exposed to the direct action of the fire they are in many cases objectionable. Surfaces concave towards the fire and heated gases, and flat surfaces deviating somewhat from the perpendicular, are probably the most effective; for from these the steam will rise freely and the water will be brought more readily in contact with the plates, the surfaces being in a position more favourable for circulation ; provided only that the water spaces are not too con- 
fined, a fault to be found frequently in locomotive and marine boilers. These remarks will suffice to explain the writer's object in making a distinction in the kinds of heating surface in the boilers experimented upon; and he would express a hope that this important question may be made the subject of further investigation.

The following are the particulars of the experiments given in Table III :-

A-Cylindrical boiler with 2 fues. Each trial with this boiler continued during a whole week of 60 working hours. The fuel consumed included that required for raising steam every morning. The evaporation per $\mathrm{lb}$. of fuel is therefore less than would have been the case, had each trial extended over only 6 or 7 hours, as in some of the other experiments.

B-Cylindrical boiler with 2 flues. This experiment also extended over four working days, under similar cireumstanees to the preceding.

C-Cylindrical boiler with 2 fues, shown in Figs. 1 and 2, Plate 31. This boiler having worked only a few weeks was free from seale, which should be borne in mind in comparing it with the other boilers. In the first experiment the mean of two trials of 12 hours each is given. The temperature in the main flue leading to the chimney averaged $548^{\circ} \mathrm{Fahr}$. as measured by Gauntlett's pyrometer, and the evaporation was $7 \cdot 48 \mathrm{lbs}$. of water per $\mathrm{lb}$, of fuel. Comparing this with the first experiment with the Galloway multitubular boiler $\mathbf{H}$, shown in Figs. 10 to 13, Plate 32, which was also new and free from scale and tried under precisely similar conditions, it will be observed that the evaporation is $8.03 \mathrm{lbs}$. of water per $1 \mathrm{lb}$. of fuel or nearly $7 \frac{1}{2}$ per cent. greater with the latter, while the temperature in the main flue was only $416^{\circ} \mathrm{Fahr}$; showing that a larger portion of the heat had been abstracted from the gases during their passage through the flues in the Galloway multitubular boiler, owing to the larger area and more particularly to the better description of heating surface. A second experiment with the cylindrical two-flued boiler $\mathrm{C}$ shows the evaporation in the course of 48 successive hours, the rate of combustion during the night being only about one half of that during the day. The evaporation is considerably less than in the 
first experiment, amounting to only $6.88 \mathrm{lbs}$. of water per lb. of fuel, probably owing to the fires having been neglected, an excess of air passing through the grate where not covered with fuel. A corresponding second experiment with the Galloway multitubular boiler $\mathbf{H}$ shows a similar result, the evaporation being diminished to $7 \cdot 71 \mathrm{lbs}$. of water per $\mathrm{lb}$. of fuel; but in this case also the superiority of the same boiler is exhibited by an increased evaporation of 12 per cent. over the boiler $\mathrm{C}$. In this instance there has been an excellent opportunity for comparison, each of the boilers compared having been worked on the same premises under the conditions best suited to them.

D-Cylindrical boiler with 5 fues, shown in Figs. 3 and 4 , Plate 31. This boiler with an external furnace gave anything but a satisfactory result, the evaporation being only $6 \cdot 16 \mathrm{lbs}$. of water per lb. of fuel. Various alterations were then made in the size of firegrate, the mode of setting, and the admission of air, in order to effect perfect combustion of the fuel; but although this seemed to be attained, the evaporative power could not be inereased, as shown in the second experiment given in the table. Comparing this with an old Galloway boiler $F$, working under similar conditions, a marked difference is apparent, the evaporation per $\mathrm{lb}$. of fuel being $7 \cdot 35 \mathrm{lbs}$. of water or nearly 20 per cent. higher with the latter.

E-Multiflued boiler with 7 fues, shown in Figs. 5 and 6, Plate 31. The evaporation in this boiler was $7 \cdot 41 \mathrm{lbs}$. of water per lb. of fuel, or nearly the same as that obtained in the first experiment with the new cylindrical two-flued boiler $\mathrm{C}$; but the evaporation per square foot of grate per hour was 8 per cent. greater with the multiflued boiler, the grate surface of which was 73 per cent. larger and the total effective heating surface 50 per cent. larger than in the boiler $\mathbf{C}$, as shown in Table IV. The relative values of the fuel used in the two cases not having been ascertained, a fair comparison can scarcely bo drawn; but it is probable that the advantage would be on the side of the multiflued boiler $\mathrm{E}$.

F-Galloway boiler; has been already referred to and compared with the cylindrical five-flued boiler $D$.

G-Galloway boiler, shown in Figs. 7, 8, and 9, Plate 32. In the first experiment with this boiler when burning slack of a very 
inferior quality, the evaporation was $7 \cdot 25 \mathrm{lbs}$. of water per lb. of fuel or 3 per cent. less than in the first experiment with the new cylindrical two-flued boiler $\mathbf{C}$; but in a second experiment with a better quality of fuel the evaporative duty appears to be equal in the two boilers. The boiler $G$ having worked for many years, its evaporative power would to some extent be impaired by incrustation on the plates; but as regards the rate of evaporation per square foot of grate per hour it stands much higher than any other boiler in the table.

H-Galloway Multitubular boiler, shown in Figs. 10 to 13, Plate 32. This boiler has been already compared with the new cylindrical twoflued boiler $\mathrm{C}$, and its superior evaporative duty is also apparent as compared with the preceding Galloway boiler $G$.

I-Multitubular boiler, shown in Figs. 14 to 17, Plate 32. In the first experiment this boiler appears to surpass all the preceding in evaporative duty, the evaporation being $8.36 \mathrm{lbs}$. of water per $1 \mathrm{~b}$. of fuel ; but as the coal here used was of a much better quality, probably the best steam coal in Lancashire, the superiority of this boiler may not be so great as would at first appear. The construction is undoubtedly good; but seeing that the Galloway muititubular boiler $\mathrm{H}$ with a much inferior quality of fuel falls little short in evaporative duty, it is probable that with the same quality of fuel the latter would give the higher evaporative duty. On the other hand it must be observed that the rate of evaporation per square foot of grate per hour is considerably higher in the multitubular boiler I. The second and third experiments with this boiler show the evaporative duty during two consecutive weeks : these may be compared with the weekly results of the cylindrical two-flued boiler $A$, over which they exhibit a marked superiority, the conditions of the experiments being similar in the two cases, excepting in regard to pressure of steam and quality of fuel as already mentioned.

The relative economy of the various classes of boilers as regards eraporation of water and consumption of fuel having thus been shown, the next question to be considered is their relative durability and the defects peculiar to each. 
The Wagon boiler is now rapidly disappearing from Lancashire and Yorkshire, being unsuited for the increased pressure of steam which has of late years been generally employed. It is therefore scarcely necessary to refer to this construction of boiler, excepting to remark that in the concave surface exposed to the fire and the vertical curved surfaces of the sides a very effective kind of heating surface is presented. The bottom of the boiler where it rests on the seating is the part where repairs are most frequently required, owing principally to imperfect circulation of the water at that part, resulting in fracture or leakage and corrosion of the plates.

The Butterley boiler, similar in form at the furnace, is liable to the same defect; but for a moderate pressure is decidedly to be preferred to the cylindrical boiler without flues.

The chief merits of the Cylindrical boiler without flues consist in great strength and simplicity of construction and in its being suited to rough usage; but as regards economy in fuel little can be said in its favour. On this account it has been principally confined to collieries and ironworks, where economy in fuel is generally too little regarded. The chief defect to be attributed to this class of boiler is fracture of the plates over the fire; but this is frequently much aggravated from an error in setting, too little height being allowed between the underside of the boiler and the firegrate or at the bridge, under which circumstances even the best plates will not long escape injury from the intensity of the fire. Various combinations of the plain cylindrical boiler have been introdnced, with a view to increased economy, but very partial success has attended these endeavours : amongst them may be mentioned Woolf's and the French boiler and others of more recent date. These however appear to possess few merits to recommend them; and it may be unnecessary to allude to them further than to observe that in the French boiler a large area of heating surface is presented, nearly the whole of the lower vessels containing the water being exposed to the flame or heated gases. But it is evident that in this arrangement the circulation of the water must be exceedingly defective, there being only two or three connecting. pipes to serve as a communication between the upper and lower vessels: the steam generated in the latter not finding ready means of exit accumulates and allows the 
plates at the top to become overheated and fractured from non-contact of the water; while fractures occur also at the bottom in consequence of insufficient circulation of water, thus rendering frequent and expensive repairs necessary. There is moreover great liability to priming, owing to the obstruction offered to the escape of steam from the lower vessels : it has been observed in the working of these boilers that, instead of a regular ascending current of steam, its ascent from the lower vessels is intermittent, and much water is carried along with it. To remedy this defect, plates or pipes have in some instances been introduced to separate the ascending and descending currents; but even then the results have not been satisfactory, and this boiler though still extensively used in France is but little adopted in this country.

The Cornish boiler or cylindrical boiler with internal flues is, as has been shown in Table I, by far the most common form of boiler in Lancashire and Yorkshire. It is simple in construction, affording great facility for cleaning and repairs; but on the other hand possesses serious defects, the principal of which are imperfect circulation of water and weakness of the flues: the former being the cause of unequal expansion in the boiler, producing straining of the seams and sometimes fracture of the plates; and the latter being the most frequent source of explosion. With fires in the flues, the smaller the flue the greater is its strength; but the more imperfect is also the combustion, owing to the cooling effect of the plates upon the fuel and the gases. With large flues, it will be seen that the spaces $\mathbf{S ~ S}$, Fig. 2, Plate 31, between the boiler shell and flues, being necessarily small, the ascending currents from the upper part of the flues exposed to the action of the fire and from the flue surfaces of the shell must greatly impede the flow of the downward current, and in some cases when very narrow almost entirely prevent it: consequently the difference of temperature between the upper and under side of the boiler will be considerable, especially when first raising steam; the effects of which are unequal expansion, leakage at the seams, and not unfrequently fracture of the plates near the centre at the under side. Another defect common to this boiler is the fracture of the end plates or angle iron rings by which the flues are attached. This appears to be caused by the repeated alternate strains to which these parts are 
subjected : when the boiler is empty it is strained by the weight of the flues, if they are supported only at the ends; and when at work by the reverse strain due to the buoyant action of the water upon the flues and the pressure upon the ends. To remedy this some makers have adopted the plan of supporting the flues in the middle by means of a plate stay attached by angle iron to the flues and to the shell, an arrangement which has of late become more general, since it has been shown by some recent experiments made by $\mathrm{Mr}$. Fairbairn and the writer that the strength of flues varies nearly in the inverse ratio to their length. The most efficient mode of strengthening such flues is however by the adoption of Adamson's plan of flanged seams, as shown in Fig. 17, Plate 32. Beyond the fact above stated, that within certain limits the strength of cylindrical flues varies inversely as their length, little is known on this subject. The ultimate strength of flues still remains a matter of uncertainty; for while some flues 3 feet diameter made of $\frac{3}{8}$ inch plates and exceeding 30 feet in length have continued working for years at a pressure of not less than 65 lbs. per square inch above the atmosphere, others of smaller diameter and equal thickness but shorter length, and therefore supposed to be of greater strength, have collapsed apparently at a lower pressure. The experiments already made on this subject have certainly been of some service, but are by no means conclusive as to the absolute strength of fues, especially if there be any deriation from the cylindrical form.

The Multifued boiler may be considered an intermediate stage between the Cornish and the multitubular boiler, and has the advantage of being stronger in the flues and probably more economical in fuel than the former.

The Galloway boiler is in one respect superior to all the other boilers mentioned: namely in having better circulation of the water by means of the vertical pipes in the flues, the heat being carried off as rapidly as received by these surfaces, against which the heated gases impinge. An equality of temperature consequently prevails throughout the whole body of the water, and a boiler of this construction is therefore not-subjected to the severe strains produced by unequal expansion, which so frequently cause leakage and fracture in the under side of Cornish and multitubular boilers. In economy of fuel it has 
already been shown that this boiler holds a high position, which appears to be mainly due to the large proportion of nearly vertical heating surface, and the more perfect circulation of the water. Objections have been raised against the oval flue on the ground of weakness of construction; but with the water pipes as stays sufficient strength is obtained for moderately high pressure, and by the adoption of the plan of flanged seams before mentioned the strength conld be increased beyond any present requirements.

The Multitubular boiler, though universally admitted to be economical in fuel, has generally fallen into disrepute, in consequence of the frequent repairs required, and the difficulty or impossibility of cleaning properly where there is much sediment from the water: Where set without external flues, leakage on the underside and consequent corrosion of the plates have usually taken place. This howerer has been to some extent remedied by constructing a return flue underneath, so as to maintain more nearly an equality of temperature throughout the boiler; the cause of failure being as already explained the unequal expansion of the upper and lower parts of the boiler from want of proper circulation of the water. Owing to the difficulty of removing sediment in this boiler, a solid mass is formed in the course of time, preventing access of the water to the tubes and thus seriously impairing their efficiency and durability. Tubes generally have been made unnecessarily long, a considerable portion of their length being of little if any value for generating steam : for the gases on entering a tube, having imparted a large portion of their heat to the surface with which they first come in contact, continue in their comparatively cooled state in contact with the tube, preventing in a great measure the transmission of heat from the hotter gases in the centre of the tube. On this account in several multitubular boilers of recent make the length of the tubes has been considerably reduced, and with decided advantage. In the Galloway multitubular boiler the small tubes are very short, not exceeding 3 feet in length.

The writer has not thought it necessary in this paper to enter upon the question of combustion though intimately connected with that of economy of fuel, that part of the subject having been so fully discussed 
by others. In the experiments above detailed no particular attention was directed to the question of smoke: the usual mode of firing was followed, and there was no great emission of smoke, the air being partially admitted through the firedoors, except in the Galloway boiler G, where it entered entirely through the grate; but the combustion cannot be said to have been perfect, nor therefore do the tables here given show the absolute value of the fuel used.

There is no doubt that great as has been the progress of late years in the construction of steam engines and the economical use of steam by working expansively, this has not been accompanied by equal progress in the construction of steam boilers; for whatever may be the scientific knowledge in the latter branch of engineering it certainly is not favourably exhibited in the generality of boilers in present use. On the contrary the laws of combustion and evaporation seem generally to have been almost entirely ignored, and waste of fuel and rapid deterioration of boilers have been the natural consequences. In concluding these remarks the writer would express a hope that, imperfectly as this subject has been treated, sufficient has been said to show the necessity of further investigations, and to induce other members of the Institution to prosecute these enquiries, which cannot fail to prove of great practical value to the manufacturing community. 
TABLE II.

Consumption of Fuel in different Boilers.

\begin{tabular}{|c|c|c|c|c|c|c|}
\hline Description & Pressure of Steam & Nomber & Indicated & Ayerage & $\begin{array}{l}\text { Ave } \\
\text { Consumpt } \\
\end{array}$ & tigan of tuel. \\
\hline $\begin{array}{c}\text { of } \\
\text { Boiler. }\end{array}$ & $\begin{array}{c}\text { per square inch } \\
\text { above atmosphere. }\end{array}$ & $\begin{array}{c}\text { of } \\
\text { Boilers. }\end{array}$ & $\begin{array}{c}\text { Horse power } \\
\text { of Engines. }\end{array}$ & $\begin{array}{c}\text { Horse power } \\
\text { per Boiler. }\end{array}$ & $\begin{array}{c}\text { Yer } \\
\text { Boiler } \\
\text { per hour. }\end{array}$ & $\begin{array}{c}\text { Ter Horse } \\
\text { power } \\
\text { per hour. }\end{array}$ \\
\hline & Ibs. Lbs. & $?$ & $\begin{array}{r}\text { II. } P \text {. } \\
204\end{array}$ & H. P. & Lus. & $\begin{array}{l}\text { Lbs. } \\
5.08\end{array}$ \\
\hline Pailara & & & 749 & 107 & 567 & - \\
\hline & Totals .. & 9 & 953 & 106 & 556 & $5 \cdot 25$ \\
\hline Boilers & 16 to 30 & 4 & 165 & 41 & 307 & $7 \cdot 49$ \\
\hline without & 31 to 45 & 4 & 149 & 37 & 345 & $9 \cdot 32$ \\
\hline internal flues. & Totals .. & 8 & 314 & 39 & 326 & $8 \cdot 36$ \\
\hline & up to 15 & 23 & 2102 & 91 & 479 & $5 \cdot 26$ \\
\hline & 16 to 30 & 208 & 22779 & 110 & 580 & $5 \cdot 27$ \\
\hline Boulers & 31 to 45 & 131 & 15303 & 117 & 582 & $4 \cdot 98$ \\
\hline with & 46 to 60 & 78 & 10983 & 141 & 595 & $4 \cdot 22$ \\
\hline & above 60 & 36 & 5923 & 165 & 634 & $3 \cdot 84$ \\
\hline & Totals & 476 & 57090 & 120 & 582 & 4.85 \\
\hline & 16 to 30 & 1 & 69 & 69 & 446 & 6.46 \\
\hline Multiflued & 31 to 45 & 8 & 816 & 102 & 531 & $5 \cdot 21$ \\
\hline Boilers. & 46 to 60 & 5 & 1056 & 211 & 748 & $3 \cdot 55$ \\
\hline & Totals . & 14 & 1941 & 139 & 602 & $4 \cdot 33$ \\
\hline & 16 to 30 & 29 & 3248 & 112 & 644 & $5 \cdot 75$ \\
\hline Galloway & 31 to 45 & 31 & 3960 & 128 & 578 & $4 \cdot 52$ \\
\hline Boilers. & 46 to 60 & 14 & 1863 & 133 & 582 & $4: 38$ \\
\hline & Totals . & 74 & 9071 & 123 & 605 & $4 \cdot 92$ \\
\hline & up to 15 & 2 & 162 & 81 & 614 & $7 \cdot 58$ \\
\hline & 16 to 30 & 1 & 162 & 162 & 1039 & $6 \cdot 41$ \\
\hline Prilore & 31 to 45 & 16 & 2406 & 150 & 482 & $3 \cdot 21$ \\
\hline & 46 to 60 & 21 & 4064 & 194 & 647 & $3 \cdot 34$ \\
\hline & Totals .. & 40 & 6794 & 170 & 589 & $3 \cdot 46$ \\
\hline
\end{tabular}


TABLE III.

Evaporative Duty of different Boilers.

\begin{tabular}{|c|c|c|c|c|c|c|c|c|c|c|c|}
\hline \multirow{3}{*}{\begin{tabular}{c|} 
Boiler \\
experimented \\
upon.
\end{tabular}} & \multirow{3}{*}{$\begin{array}{c}\text { No. } \\
\text { of } \\
\text { trials. }\end{array}$} & \multirow{3}{*}{$\begin{array}{c}\text { Length } \\
\text { of } \\
\text { trials. }\end{array}$} & \multirow{3}{*}{$\begin{array}{l}\text { Pressure } \\
\text { of Steam } \\
\text { per } \\
\text { sq. in. } \\
\text { above } \\
\text { atm. }\end{array}$} & \multirow{3}{*}{$\begin{array}{l}\text { Area } \\
\text { of } \\
\text { Fire- } \\
\text { grate. }\end{array}$} & \multicolumn{2}{|c|}{ Fuel consumed. } & \multicolumn{4}{|c|}{ Water evaporated. } & \multirow{3}{*}{ Description of Fuel. } \\
\hline & & & & & \multirow[b]{2}{*}{$\begin{array}{c}\text { Per } \\
\text { hour. }\end{array}$} & \multirow[b]{2}{*}{$\begin{array}{c}\text { Per } \\
\text { sq. ft. } \\
\text { of grate } \\
\text { perhour. }\end{array}$} & \multicolumn{2}{|c|}{ From $62^{\circ}$ Fahr. } & \multicolumn{2}{|c|}{ Per lb. of Fuel. } & \\
\hline & & & & & & & $\begin{array}{c}\text { Per } \\
\text { hour. }\end{array}$ & $\mid \begin{array}{c}\text { Per } \\
\text { sq. ft. } \\
\text { of grate } \\
\text { perhour. }\end{array}$ & $\begin{array}{l}\text { Froma } \\
62^{\circ} \\
\text { Fahr. }\end{array}$ & $\begin{array}{l}\text { From } \\
212^{\circ} \\
\text { Fahr. }\end{array}$ & \\
\hline A & 2 & $\begin{array}{l}\text { Hours. } \\
120\end{array}$ & $\begin{array}{l}\text { Lbs. } \\
20\end{array}$ & $\begin{array}{l}\text { Sq. Ft. } \\
38\end{array}$ & $\begin{array}{l}\text { Lbs. } \\
688\end{array}$ & $\begin{array}{l}\text { Lbs. } \\
18 \cdot 1\end{array}$ & $\begin{array}{l}\text { Lbs. } \\
4193\end{array}$ & $\begin{array}{c}\text { Lbs. } \\
110 \cdot 3\end{array}$ & $\begin{array}{l}\text { Lbs. } \\
6 \cdot 09\end{array}$ & $\begin{array}{l}\text { Lbs. } \\
7 \cdot 02\end{array}$ & Burgey of good quality; \\
\hline B & 1 & 40 & 40 & 35 & 717 & $20 \cdot 5$ & 4269 & $122 \cdot 0$ & $5 \cdot 95$ & $6 \cdot 86$ & Plodder Mine, Lancashire. \\
\hline$C\left\{\begin{array}{l}1 \text { st exp. } \\
\text { 2nd } "\end{array}\right.$ & $\begin{array}{l}2 \\
1\end{array}$ & $\begin{array}{l}24 \\
48\end{array}$ & $\begin{array}{l}55 \\
49\end{array}$ & $\begin{array}{l}30 \\
30\end{array}$ & $\begin{array}{l}355 \\
272\end{array}$ & $\begin{array}{r}11 \cdot 8 \\
9 \cdot 1\end{array}$ & $\begin{array}{l}2656 \\
1871\end{array}$ & $\begin{array}{l}88 \cdot 5 \\
62 \cdot 4\end{array}$ & $\begin{array}{l}7 \cdot 48 \\
6 \cdot 88\end{array}$ & $\begin{array}{l}8 \cdot 61 \\
7 \cdot 92\end{array}$ & $\begin{array}{l}\text { Slack of good quality ; } \\
\text { Schofield HaIl, Iancashire. }\end{array}$ \\
\hline D $\left\{\begin{array}{l}\text { lst exp. } \\
2 \text { nd }\end{array}\right.$ & $\begin{array}{l}5 \\
8\end{array}$ & $\begin{array}{l}32 \\
47\end{array}$ & $\begin{array}{l}32 \\
39\end{array}$ & $\begin{array}{l}30 \\
30\end{array}$ & $\begin{array}{l}613 \\
655\end{array}$ & $\begin{array}{l}20 \cdot 4 \\
21 \cdot 8\end{array}$ & $\begin{array}{l}3777 \\
4085\end{array}$ & $\begin{array}{l}125 \cdot 9 \\
134 \cdot 5\end{array}$ & $\begin{array}{l}6 \cdot 16 \\
6 \cdot 16\end{array}$ & $\begin{array}{l}7 \cdot 09 \\
7 \cdot 09\end{array}$ & $\begin{array}{l}\text { Burgey of average quality; } \\
\text { West Leigh, Lancashire. }\end{array}$ \\
\hline $\mathbf{E}$ & 16 & 56 & 40 & 52 & 670 & $12 \cdot 9$ & 4964 & $95 \cdot 5$ & $7 \cdot 41$ & $8 \cdot 53$ & Burgey of good quality; Duckworth Hall, Lanc. \\
\hline $\mathbf{F}$ & 3 & 21 & 32 & 30 & 512 & $17 \cdot 1$ & 3765 & $125 \cdot 5$ & $7 \cdot 3 \breve{J}$ & $8 \cdot 47$ & Burgey of average quality; West Leigh, Lanc. \\
\hline G $\left\{\begin{array}{l}\text { 1st exp. } \\
\text { 2nd }, "\end{array}\right.$ & $\begin{array}{l}2 \\
1\end{array}$ & $\begin{array}{l}21 \\
10 \frac{1}{2}\end{array}$ & $\begin{array}{l}40 \\
40\end{array}$ & $\begin{array}{l}38 \frac{1}{2} \\
38 \frac{1}{2}\end{array}$ & $\begin{array}{l}917 \\
896\end{array}$ & $\begin{array}{l}23 \cdot 8 \\
23 \cdot 2\end{array}$ & $\begin{array}{l}6648 \\
6702\end{array}$ & $\begin{array}{l}172 \cdot 7 \\
174 \cdot 1\end{array}$ & $\begin{array}{l}7 \cdot 25 \\
7 \cdot 48\end{array}$ & $\begin{array}{l}8 \cdot 35 \\
8 \cdot 61\end{array}$ & $\begin{array}{l}\text { Slack of inferior quality ; Yorkshire. } \\
\text { Burgey of good quality; Yorkshire. }\end{array}$ \\
\hline H $\left\{\begin{array}{l}\text { Ist exp. } \\
\text { 2nd },\end{array}\right.$ & $\begin{array}{l}2 \\
1\end{array}$ & $\begin{array}{l}24 \\
48\end{array}$ & $\begin{array}{l}51 \\
48\end{array}$ & $\begin{array}{l}30 \\
30\end{array}$ & $\begin{array}{l}357 \\
275\end{array}$ & $\begin{array}{r}11 \cdot 9 \\
9 \cdot 2\end{array}$ & $\begin{array}{l}2865 \\
2119\end{array}$ & $\begin{array}{l}95 \cdot 5 \\
70 \cdot 6\end{array}$ & $\begin{array}{l}8 \cdot 03 \\
7 \cdot 71\end{array}$ & $\begin{array}{l}9 \cdot 24 \\
8 \cdot 88\end{array}$ & $\begin{array}{l}\text { Slack of good quality ; } \\
\text { Schofield Hall, Lancashire. }\end{array}$ \\
\hline $\mathrm{I}\left\{\begin{array}{l}\text { 1st exp. } \\
\text { 2nd } " \\
\text { 3rd } "\end{array}\right.$ & $\begin{array}{l}2 \\
1 \\
1\end{array}$ & $\begin{array}{l}7 \frac{1}{2} \\
72^{2} \\
67\end{array}$ & $\begin{array}{l}60 \\
60 \\
60\end{array}$ & $\begin{array}{l}30 \\
30 \\
30\end{array}$ & $\begin{array}{l}450 \\
468 \\
462\end{array}$ & $\begin{array}{l}15 \cdot 0 \\
15 \cdot 6 \\
15 \cdot 4\end{array}$ & $\begin{array}{l}3762 \\
3659 \\
\mathbf{3 7 3 3}\end{array}$ & $\begin{array}{l}125 \cdot 4 \\
122 \cdot 0 \\
124 \cdot 4\end{array}$ & $\begin{array}{l}8 \cdot 36 \\
7 \cdot 82 \\
8 \cdot 08\end{array}$ & $\begin{array}{l}9 \cdot 62 \\
9 \cdot 00 \\
9 \cdot 30\end{array}$ & $\begin{array}{l}\text { Burgey of very good quality ; } \\
\text { Oldham Black Mine, } \\
\text { Lancashire. }\end{array}$ \\
\hline
\end{tabular}

A,B,C-Cylindrical boilers with 2 flues; D-Cylindrical with 5 flues; E-Multiflued with 7 flues; F,G-Galloway; H-Galloway Multitubular; I-Multitubular. 
TABLE IV.

Area of Heating Surface in different Boilers.

\begin{tabular}{|c|c|c|c|c|c|c|c|c|c|c|c|}
\hline \multirow{3}{*}{$\begin{array}{l}\text { Boiler } \\
\text { experimented } \\
\text { upon. }\end{array}$} & \multirow{2}{*}{\multicolumn{4}{|c|}{$\begin{array}{l}\text { Dimensions } \\
\text { of Boiler. }\end{array}$}} & \multirow{3}{*}{$\begin{array}{l}\text { Area } \\
\text { of } \\
\text { Firegrate. }\end{array}$} & \multicolumn{6}{|c|}{ Area of Heating Surface. } \\
\hline & & & & & & In & $\operatorname{ces}$. & & In Flues & & Total \\
\hline & \multicolumn{2}{|c|}{ Length. } & \multicolumn{2}{|c|}{ Diameter. } & & Concave. & Convex. & Concave. & Convex. & Vertical. & Area. \\
\hline & & Ins. & & Ins. & sq. Ft. & Sq. Ft. & Sq. Ft. & Sq. Ft. & Sq. Ft. & Sq. Fit. & Sq. Ft. \\
\hline A & 28 & 0 & 8 & 6 & 38 & 90 & ... & 207 & 280 & 13 & 590 \\
\hline B & 28 & 0 & $\tau$ & 6 & 35 & 84 & $\cdots$ & 194 & 250 & 12 & 540 \\
\hline $\mathrm{C}$ & 26 & 0 & 6 & 6 & 30 & 72 & $\ldots$ & 154 & 227 & 10 & 463 \\
\hline D & 18 & 0 & 8 & 3 & 30 & $\ldots$ & 98 & 252 & 157 & 23 & 530 \\
\hline $\mathbf{E}$ & 29 & 6 & 7 & 6 & $\tilde{\delta} 2$ & 110 & $\ldots$ & 220 & 324 & 43 & 697 \\
\hline $\mathbf{F}^{\mathbf{Y}}$ & 22 & 0 & 7 & 2 & 30 & 70 & $\ldots$ & 93 & 241 & 95 & 499 \\
\hline$G$ & 30 & 0 & 7 & 0 & $38 \frac{1}{2}$ & 88 & $\ldots$ & 288 & 315 & 207 & 898 \\
\hline $\mathrm{H}$ & 26 & 0 & 6 & 6 & 30 & 72 & $\ldots$ & 230 & 227 & 70 & 599 \\
\hline$I$ & 30 & 1) & $\theta$ & 6 & 30 & 64 & $\ldots$ & 380 & $\ldots$ & 10 & 454 \\
\hline
\end{tabular}

A, B, C-Cylindrical boilers with 2 flues; D-Cylindrical with 5 flues; E-Multiflued with 7 flues; F, G-Galloway; H-Galloway Multitubular; I-Multitubular. 
Mr. Lonaridge said his object in the paper had been to give the general result of a very large number of observations upon the working of steam boilers that had come under his inspection in connexion with the Boiler Association in Manchester and the neighbourhood, in order to derive from them as far as practicable some general conclusions respecting the relative economy and durability of the different constructions of stationary boilers in most extensive use. An important question involved was which kind of heating surface proved the most efficient on the whole; and this appeared to be not yet cleared up, as several different considerations were connected with it. In some cases owing to great facility for the escape of steam from the surface where it was generated a good result was obtained in evaporative duty, although the heating surface was really of inferior form for absorbing heat: he was inclined to think that the tube-plate in a multitubular boiler evaporated nearly as much water as the tubes, in consequence of the imperfect means of escape for the steam from the surface of the tubes.

$\mathrm{He}$ wished to call attention more particularly to the Galloway multitubular boiler shown in Figs. 10 to 13, Plate 32, in which the temperature of the smokebox proved to be $132^{\circ}$ lower than in the cylindrical two-flued boiler compared with it, shown in Figs. 1 and 2, Plate 31 ; the temperature being only $416^{\circ}$ in the former instead of $548^{\circ}$ in the latter, showing a much more complete absorption of the heat by the former boiler. In this experiment the circumstances were exactly the same with both boilers, so that they could be correctly compared : the result was that $7 \cdot 48 \mathrm{lbs}$. of water were evaporated per lb. of fuel by the cylindrical two-flued boiler, whilst the Galloway multitubular boiler evaporated $8.03 \mathrm{lbs}$. of water per lb. of fuel, giving $7 \frac{1}{2}$ per cent. more duty.

The Chairman remarked that the object to be attained was the highest evaporative duty in the smallest space combined with the greatest durability of the boiler, and the great difficulty in boilers was to obtain these several advantages without unduly sacrificing any essential point. The maintenance of a good circulation in the water was one of the most important means of obtaining durability of the boiler, by preventing inequality of temperature in different portions ; 
and in some of the long boilers with double flues there was no chance of circulation of the water on account of the narrowness of the water spaces, unless by the water descending at the back end and rising at the front end.

Mr. Longridge said that proper circulation of the water in the boiler was certainly the point of greatest importance, and the fractures in the bottom of boilers would be much less likely to occur if this were sufficiently attended to. The spaces were so small in some boilers that no effective circulation of the water could take place in them, being frequently only 3 inches wide in two-flued boilers; he had known boilers of that kind 30 feet long which worked for half a day before the water at the bottom became heated to the temperature of the steam, and this inevitably led to fracture of the bottom plates from the strain of unequal expansion.

Mr. J. Krrson thought the paper that had been read was of great value, especially in that district, where so many boilers were at work, and where sufficient attention was not paid in many cases to the important question of durability of the boilers as well as economy of fuel. The consideration of durability as affected by the mode of construction and setting of boilers had he believed been much disregarded in proportion to its importance, probably in consequence of the apparent commercial value being too exclusively considered in the first instance. The improvement of boilers would he thought be materially interfered with and retarded, so long as they were paid for according to the usual practice at a rate per ton; and it would be impossible that boilers economical in arrangement of material and consumption of fuel and of scientific excellence should prevail unless a different system were adopted. Nothing was more fallacious than the idea of cheap boilers, taking simply first cost into consideration; the principle of construction of boilers greatly affected their durability and the profit to be got out of them by the persons using them, and the question of first cost became but a minor consideration in comparison with the durability and cost of future maintenance and repair. He hoped that a change in the mode of charging for boilers would be made before long, placing this question on a more correct basis than the present plan, and he did not think there would be any serious commercial difficulty in making the change. 
The paper that had been read was of particular value, as a record of results derived from the extensive experience of the writer in the inspection of a very large number of boilers; and these results afforded valuable data for a comparison between the different kinds of boilers as to their permanent economy. He thought the form of boiler that had been specially pointed out in the paper as giving the best results appeared rather more complicated than he should have preferred; for simplicity of construction was a very important consideration in respect of diminishing the expense and delay of repairs.

Mr. B. Goopfellow olserved that in making comparative trials of the evaporative capabilities of boilers particular care was requisite to ascertain the quantity of water actnally evaporated, free from any loss of water by other causes; as well as to ensure exact correspondence in the circumstances of the boilers, not only as to quality of fuel, but also to have the same draught and the same management of the fire. It was very difficult on this account to arrive at the true result; and he had known some double-flue boilers that appeared to be giving much less evaporative duty than others although similar in construction. In respect of the circulation of the water in boilers, he had been led to think it not so imperfect as seemed to be supposed; he had made an experiment by inserting a short pipe 6 inches long into the end of a two-flued boiler underneath the flues near the bottom, and a similar pipe 7 feet long close to it, each pipe being closed by a cock. He found that the temperature of the water from the shorter pipe, which was $80^{\circ}$ at starting to raise the steam, rose $10^{\circ}$ when the steam was up ; but the water from the longer pipe had risen $23^{\circ}$ in the same time, showing that the heat was steadily moving through the water though slowly.

The Chalrmas remarked that the only true comparison of the efficiency of boiler's was the measurement of the water actually evaporated with the same fuel; and no correct data could be obtained from the comparison of the indicated horse power that was often made for the purpose, since in that case the boiler and engine were coupled together, and the effective value of neither of them could be ascertained; for it might be a good boiler coupled to a bad engine or the reverse, and the results obtained were unavoidably more or less fallacions from that 
circumstance. The object to be aimed at was to obtain the form of boiler that best combined the advantages of econony in consumption of fuel with durability and economy in repairs and compactness of the space occupied; the latter points were of great importance in marine boilers and many cases of stationary engines.

Mr. W. E. Carreir considered the ordinary eustom of purchasing boilers by weight without reference to construction was a great disadvantage, and led to the use of inferior forms of boilers. $\mathrm{He}$ suggested that in the Galloway multitubular boiler which had been referred to it might be advantageous to place the tubes in a separate chamber containing the feed water, so as more effectually to take up the remaining heat of the flue before reaching the chimney; and he enquired whether such a plan was not found to be economical.

Mr. LoNGRIDGE replied that in stationary boilers, although there was an advantage to be gained theoretically by heating the feed with the waste heat of the flue, yet he had found the plan was generally abandoned on account of the accumulation of soot upon the heating apparatus, which so greatly impaired its efficiency as to make it not worth the additional complication. An exception to this was $\mathrm{Mr}$. Green's apparatus, in which the surface of the heating pipes was kept free from deposit of soot by the continued action of scrapers moved slowly up and down the pipes by means of machinery; this apparatus was certainly very efficient and produced an important economy in the consumption of fuel.

The Chairman observed that this plan amounted in effect to increasing the heating surface of the boiler, by applying some additional surface that was maintained in an efficient condition for absorbing heat; and whatever construction of boiler might be adopted, the object would be to leave as little waste heat as practicable to pass away unabsorbed by the water.

Mr. S. Bastow thought the subject of the paper read was a very important one for discussion, and the paper was one of much value for the practical information and results contained in it. The question was one that was materially affected by locality, for the relative cost and quality of fuel made a great difference in the comparative value of economy in consumption of fuel as one of the objects to be aimed 
at in a boiler; where fuel was cheap and economy of space was also not of importance, a simple and cheap make of boiler that was safe and durable would be preferable. In the iron districts of the north, plain cylindrical boilers with convex ends were much used, as they were found very durable and cheap in manufacture, and these were points of greater importance there than economy in consumption of fuel; the boilers were generally of great length, 50 to 100 feet long, and about $4 \frac{1}{2}$ feet diameter, set with a "flash flue," a single flue open to the entire underside of the boiler. But whererer fuel was not very cheap, it was undoubtedly the right course to seek for the most economical form of boiler as to consumption; it was then the best plan commercially to give a larger sum for the boiler in the first instance so as to obtain a more perfect construction, and this would prove a great saving in the end.

The Crairman moved a rote of thanks to $\mathrm{Mr}$. Longridge for his paper, which was passed.

The following Paper was then read:-- 
ECONOMY \&. OF STEAM BOILERS.

Pig.1. Glindrical Boiler with Two Flues.

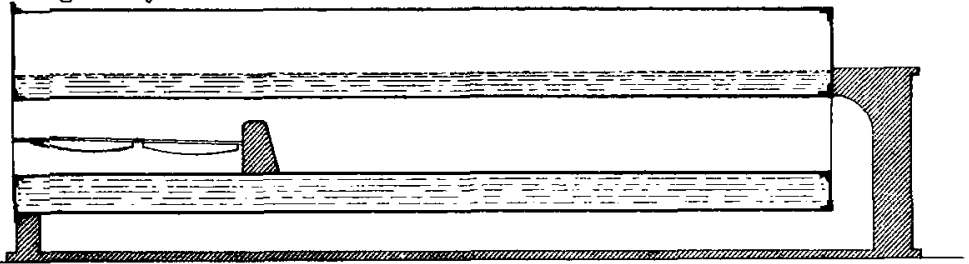

Fig. 3. Gylindrisal Boiler with Five F'lues.

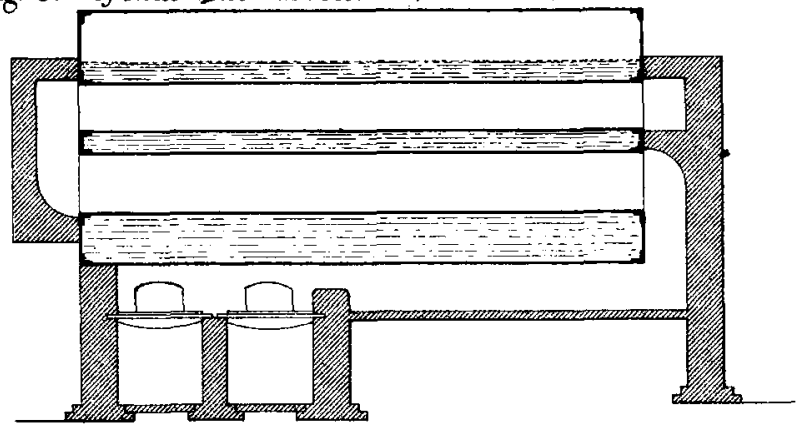

Fig. 5. Multiflued Boiler with Seren Flues.

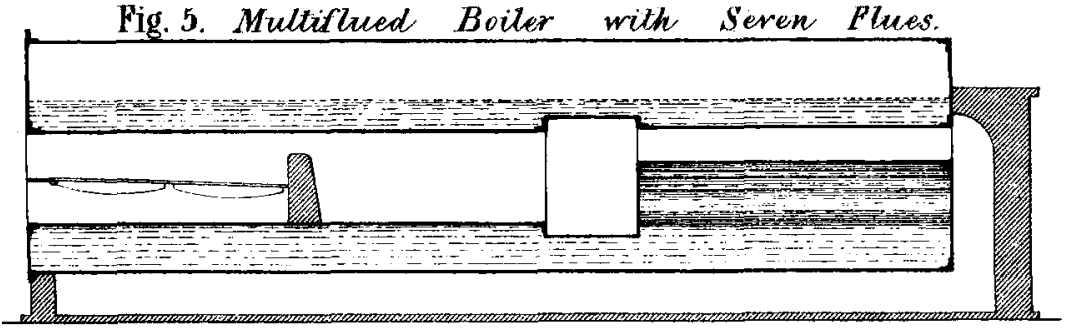

Transverse Section of Fig. 1 .

Fig. 2.

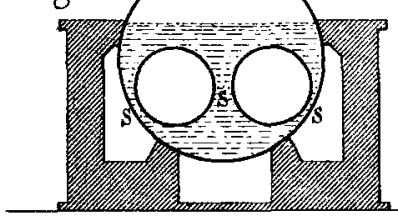

Fig. 4.

Transrerse section of Fig. 3.

Transverse Section of Fig.5.

Fig. 6.
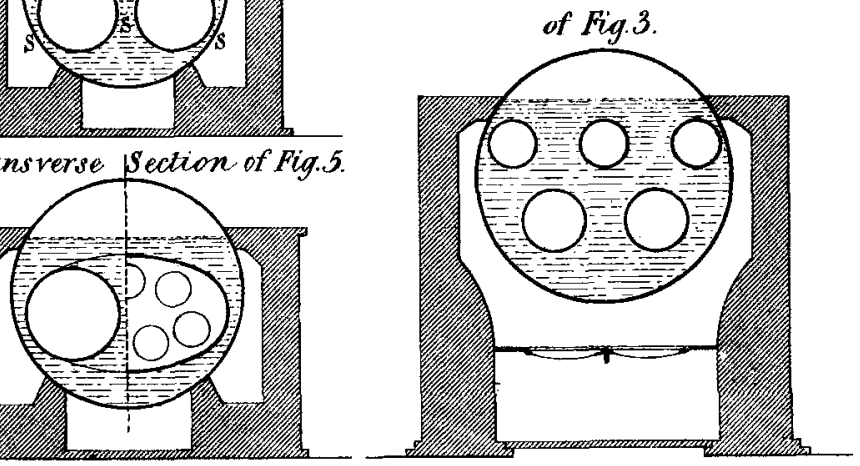

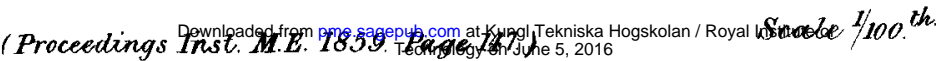


ECONOMY \&C. OF STEAM BOILERS. Plate 32.

Fig. 7. Galloway Boiler.
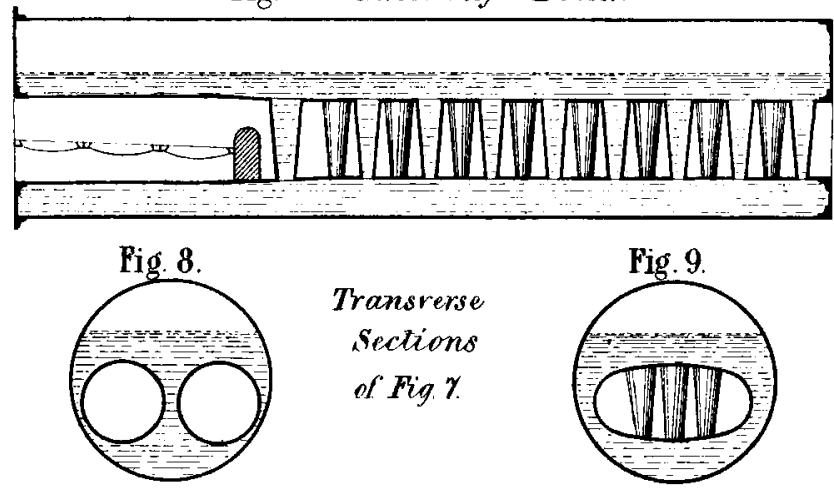

Fig.10. Galloway Multitubular Boiler.

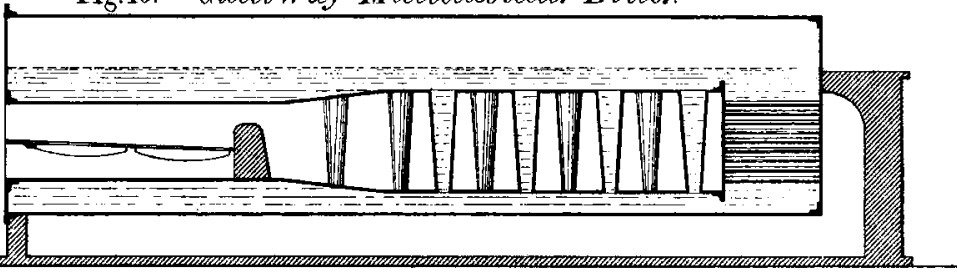

Transverse Sections of Fig. 10.

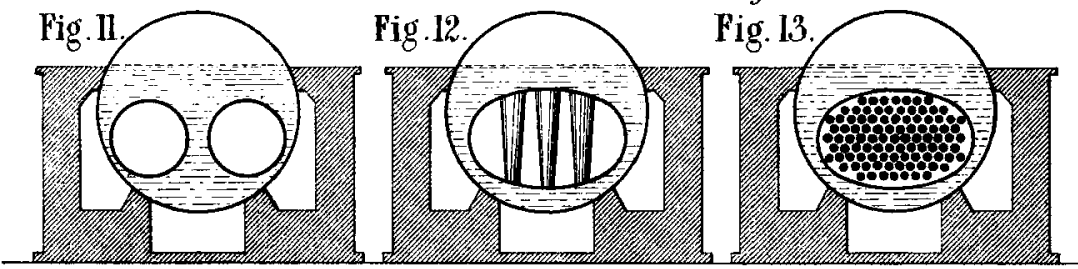

Fig. 14. Mullitubular Boiler.

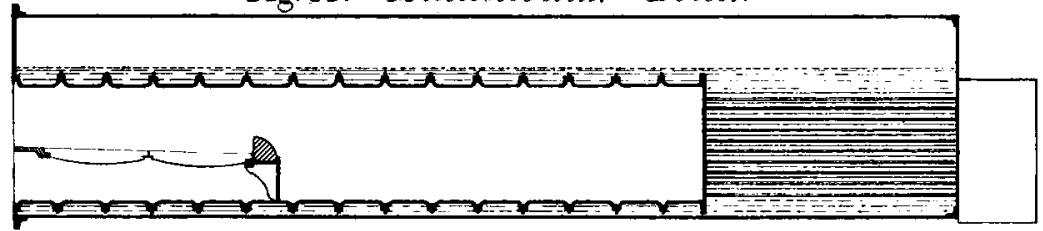

Transwerse Section of Fig.14. EndElevation of Fig.14.

Pig.15.

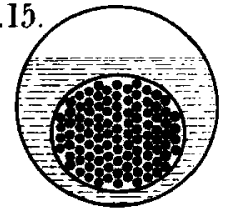

Fig.10.

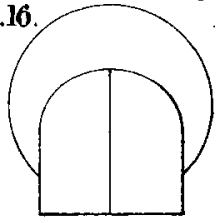

Fig.17. Flanged Joint of Plue 1 in Fig. 14, enlarged 1 scale $1 / 5^{\text {th }}$

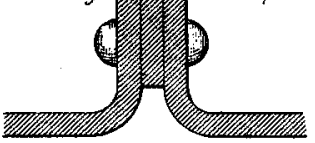

Scate $1 / 100^{\text {th }}$

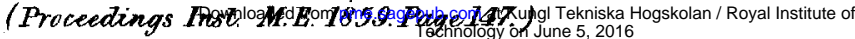

